\title{
Palaeoproterozoic age of a basement gneiss complex in the Charcot Land tectonic window, East Greenland Caledonides
}

\author{
Kristine Thrane
}

The Charcot Land tectonic window exposes crystalline basement gneisses, which form part of the foreland of the East Greenland Caledonides. These gneisses were previously believed to be Archaean in age, on the basis of imprecise K-Ar analyses carried out in the early 1980s on hornblende from amphibolitic bands and inconclusive $\mathrm{Rb} / \mathrm{Sr}$ isotope data. New U-Pb singlezircon ion microprobe analyses on the gneisses of the window yield upper intercept ages of $1916 \pm 21$ and $1928 \pm 11 \mathrm{Ma}$, and are interpreted to represent the age of crystallisation of the igneous protolith. The foreland gneisses of the Charcot Land window are similar in age to parts of the allochthonous gneiss complexes of structurally overlying thrust sheets, but the two terranes have different lithological and structural characteristics. No Archaean rocks have been identified with certainty in any of the East Greenland Caledonian foreland windows.

Keywords: Caledonides, East Greenland, geochronology, Palaeoproterozoic

Geological Survey of Denmark and Greenland, Øster Voldgade 10, DK-1350 Copenhagen K, Denmark. Present address: Geological Institute, University of Copenhagen, Øster Voldgade 10, DK-1350 Copenhagen K, Denmark. Email: Kthrane@geol.ku.dk

The Charcot Land window is located between latitudes $71^{\circ} 45^{\prime} \mathrm{N}$ and $72^{\circ} 15^{\prime} \mathrm{N}$ in the south-western part of the $1300 \mathrm{~km}$ long East Greenland Caledonides (Fig. 1). It is one of a series of tectonic windows, interpreted to expose parautochthonous foreland (Higgins \& Leslie 2000), found along the western border of the Caledonian orogen. The Gåseland window is exposed to the south at $c .70^{\circ} \mathrm{N}$ (Wenk 1961; Phillips et al. 1973), and the Målebjerg and Eleonore Sø windows to the north between latitudes $73^{\circ} 30^{\prime}-74^{\circ} 15^{\prime} \mathrm{N}$ (Leslie \& Higgins 1998; Higgins \& Leslie 2000, 2004, this volume). Further to the north, the foreland basement is also exposed in western Dronning Louise Land $\left(76^{\circ}-77^{\circ} \mathrm{N}\right.$; e.g. Strachan et al. 1992), and in the small Nørreland window ( $78^{\circ} 40^{\prime} \mathrm{N}$; Hull \& Friderichsen 1995). Apart from these restricted areas the foreland of the East Greenland Caledonides is not well known, as it is largely concealed beneath the Inland Ice to the west.

The Charcot Land window (Fig. 2) exposes a base- ment complex of grey gneisses with amphibolite bands, overlain by a cover of low to medium-grade supracrustal rocks including carbonates, volcanic rocks and siliciclastic sediments (Charcot Land supracrustal sequence; Steck 1971). Both basement and cover are cut by major Palaeoproterozoic granite intrusions (Hansen et al. 1981).

Structurally overlying the Charcot Land window are Caledonian thrust sheets comprising crystalline gneiss complexes (Flyverfjord infracrustal complex) and overlying high-grade metasedimentary rocks (Krummedal supracrustal sequence; Henriksen \& Higgins 1969, 1976). The crystalline gneisses making up the Flyverfjord infracrustal complex in Hinks Land, south-east of Charcot Land (Fig. 2), are of late Archaean age (c. 2700 Ma; Rex \& Gledhill 1974; Thrane 2002). The Flyverfjord infracrustal complex extends both southwards and northwards (Fig. 1); however, north of $72^{\circ} 50^{\prime} \mathrm{N}$ very similar looking orthogneisses have yielded Pal- 


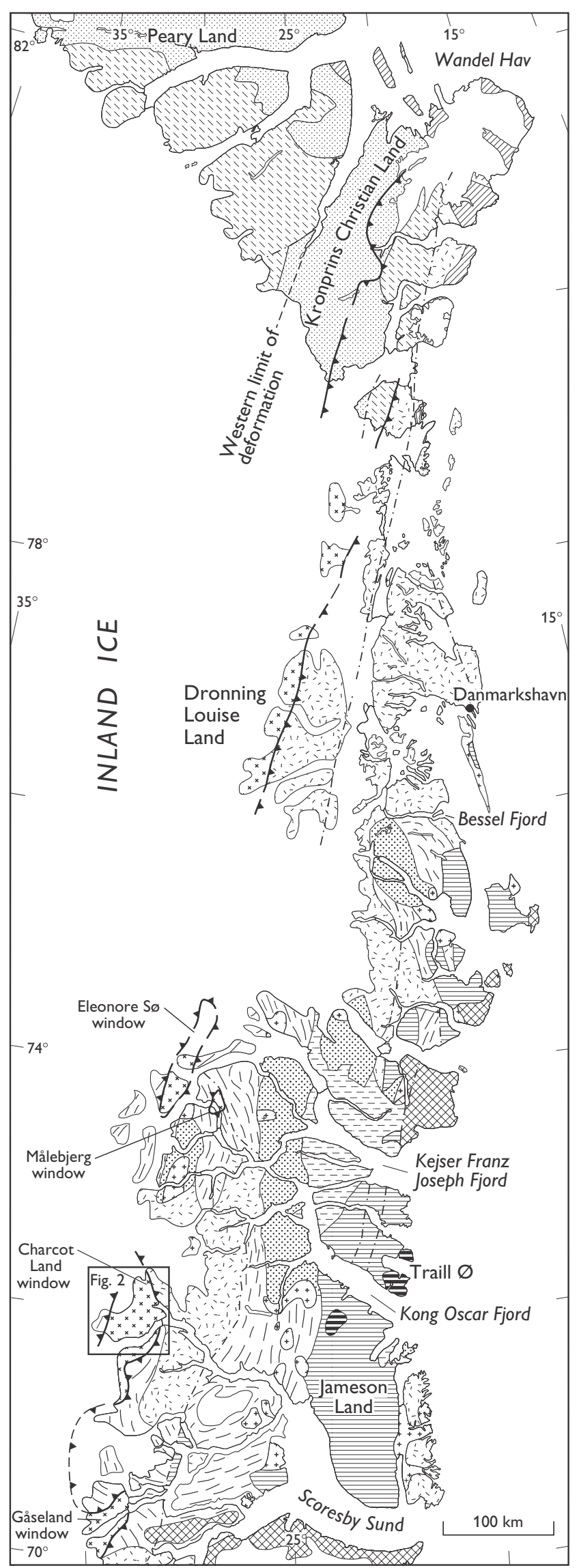

POST-CALEDONIAN

Palaeogene basalts

Palaeogene intrusions

Wandel Sea basin: Carboniferous-Palaeogene

East Greenland basin: Carboniferous-Cretaceous sediments

\section{LATE TO POST-CALEDONIAN}

Devonian - continental sediments

\section{CALEDONIAN FOLD BELT}

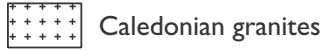

Neoproterozoic-Ordovician sediments

(East Greenland)

Neoproterozoic-Silurian sediments

(North Greenland)

Palaeo-Mesoproterozoic sediments and basalts (North Greenland)

I/, High-grade metasediments (Krummedal supracrustal sequence)

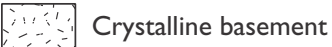

\section{CALEDONIAN FORELAND}

Neoproterozoic-Silurian sediments

(North Greenland)

Palaeo-Mesoproterozoic sediments and basalts (North and North-East Greenland)

${ }_{x^{x} x^{*} x^{x}}$ Crystalline gneisses

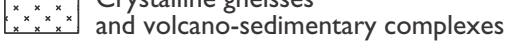

-ד Thrust

....- Fault/shear zone

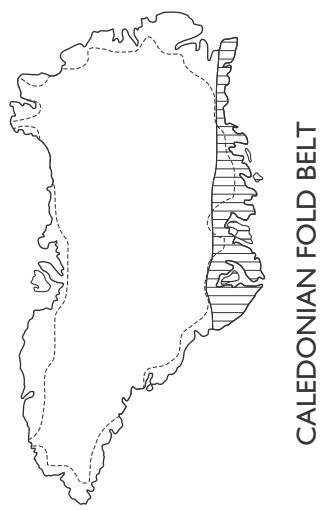

Fig. 1. Geological map of the East Greennland Caledonides. frame indicates study area shown at larger scale in Fig. 2. 
aeoproterozoic ages (c. 1900 Ma; Rex \& Gledhill 1981; Kalsbeek et al. 1993; Thrane 2002). The Krummedal supracrustal sequence, that overlies the Flyverfjord infracrustal complex as well as the similar gneiss complexes between latitudes $70^{\circ}$ and $76^{\circ} \mathrm{N}$, was deposited later than $1100 \mathrm{Ma}$ ago, and underwent high grade metamorphism with generation of granites c. $940 \mathrm{Ma}$ ago (Kalsbeek et al. 2000). The contact between the Krummedal supracrustal sequence and the structurally overlying Neoproterozoic-Ordovician sedimentary succession is a shear zone, interpreted as an extensional detachment or locally a thrust (Escher \& Jones 1998; Leslie \& Higgins 1998). The western border of the main Neoproterozoic-Ordovician outcrop in the fjord region from $72^{\circ}-75^{\circ} \mathrm{N}$ is a late orogenic extensional fault system (e.g. Hartz \& Andresen 1995). The $c .13 \mathrm{~km}$ thick Neoproterozoic Eleonore Bay Supergroup succession (Sønderholm \& Tirsgaard 1993) together with the Vendian Tillite Group (800-1000 m) and Cambro-Ordovician shelf sequence (up to $4 \mathrm{~km}$ ), constitute the highest part of the uppermost Caledonian thrust sheet (Higgins et al. 2004).

In 1968, the southern part of the Charcot Land area was mapped by the Geological Survey of Greenland (Henriksen \& Higgins 1969, 1976; Steck 1971), during a systematic regional mapping project in the Scoresby Sund region $\left(70^{\circ}-72^{\circ} \mathrm{N}\right)$. During the 1997 and 1998 Survey expeditions to the Kong Oscar Fjord region $\left(72^{\circ}-75^{\circ} \mathrm{N}\right)$, the northern part of Charcot Land was mapped by Friderichsen \& Thrane (1998). Sample collections were made for ion microprobe zircon studies, the results of which are reported here.

\section{Geological setting}

The foreland rock units exposed within the Charcot Land window include crystalline basement orthogneisses with interleaved amphibolite bands, that are overlain by a c. $2000 \mathrm{~m}$ thick succession of various metasedimentary rocks (including white marble) and metamorphosed basic extrusive and intrusive rocks (Charcot Land supracrustal sequence). These units are cut by two major granitoid intrusions which crop out widely in central Charcot Land (Fig. 2); one is a hornblende-biotite quartz diorite to granodiorite body and the other a pegmatitic muscovite granite. In southernmost Charcot Land a hornblende gabbro body intrudes the basement gneisses.

Tillit Nunatak in south-west Charcot Land takes its name from a sheared tillite resting unconformably on

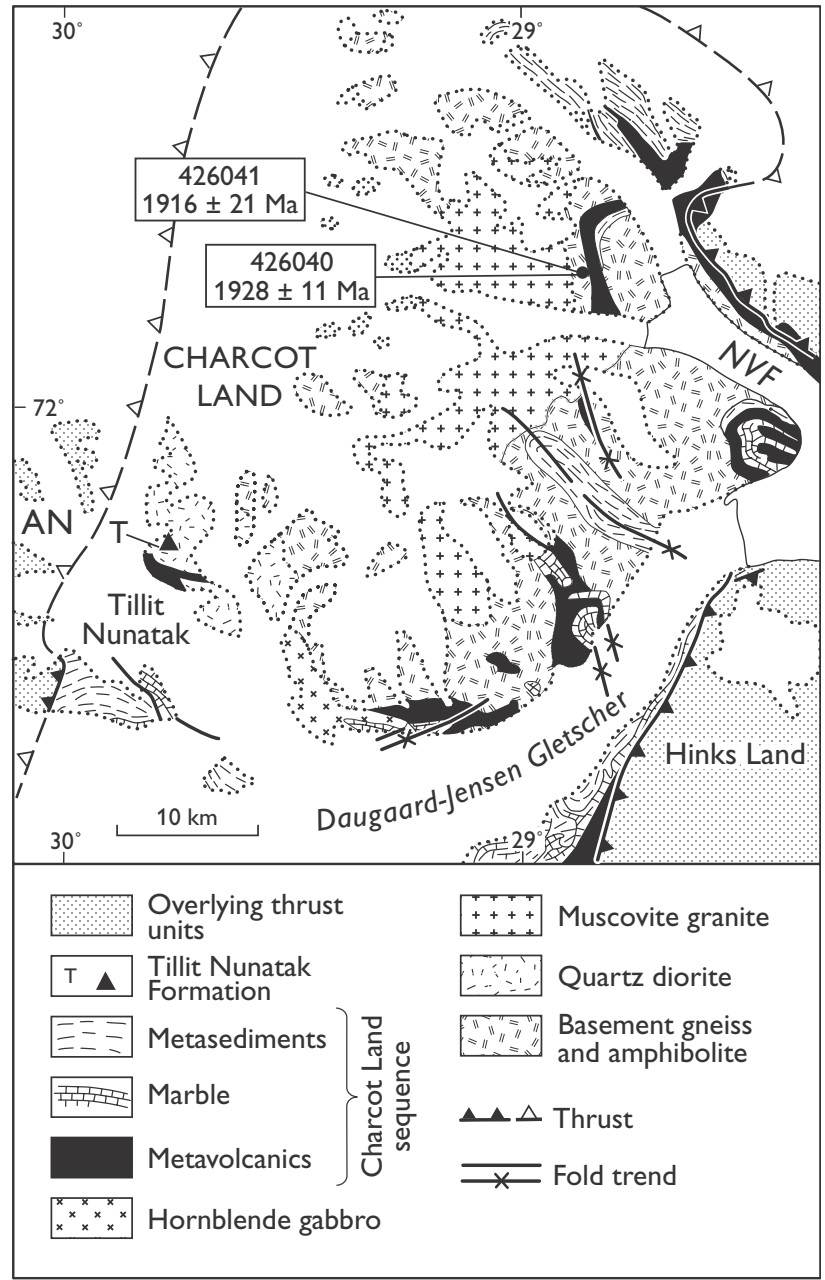

Fig. 2. Geological map of the Charcot Land window, showing major lithological divisions and sample locations. Modified from Henriksen \& Higgins (1976). The rock types of the overlying thrust sheets are undifferentiated, and include gneisses of the Flyverfjord infracrustal complex and the Krummedal supracrustal sequence. AN, Alfabet Nunatakker; NVF, Nordvestfjord.

the granodiorite intrusion. This tillite has been correlated with the Vendian tillites of the fjord zone (Moncrieff 1989), as has a similar tillite in the Gåseland window. The Charcot Land tillite is very little deformed but does contain a planar cleavage.

The Charcot Land supracrustal sequence of southernmost Charcot Land is characterised by greenschist facies metamorphism. Metamorphic grade increases towards the north-east and reaches upper amphibolite facies at $\sim 72^{\circ} \mathrm{N}$ latitude (Steck 1971). Further to the north, the metamorphic grade again decreases (Friderichsen \& Thrane 1998).

The eastern and western boundaries of the Charcot Land window are marked by major Caledonian thrusts (Fig. 2). The western thrust dips gently to the 


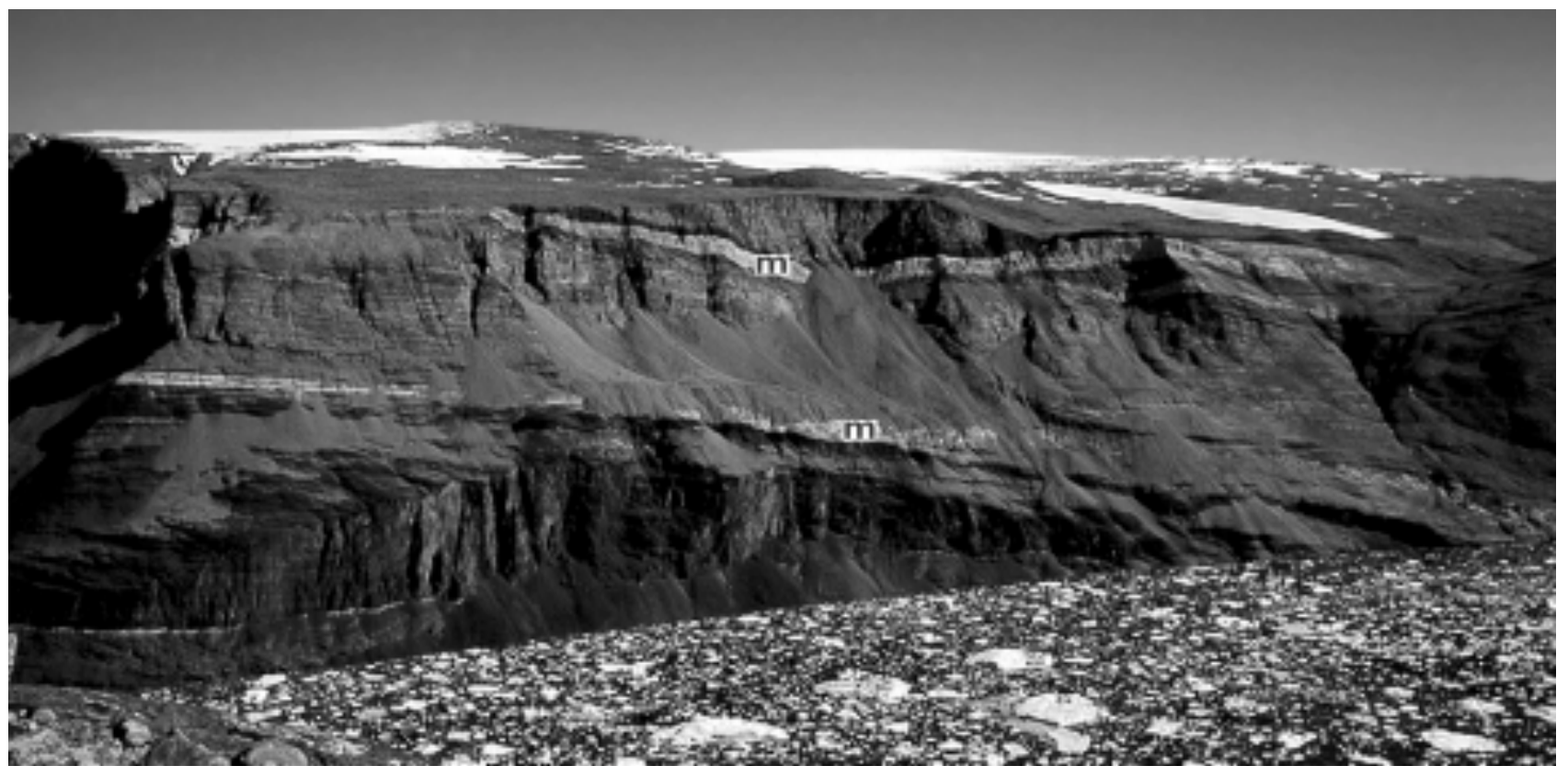

Fig. 3. Part of the major, recumbent, west-verging isoclinal fold that defines the eastern boundary of the Charcot Land window (hanging wall). The isocline is outlined by the two white marble bands (m) which form a closure just beyond the left side of the photograph. The black units are amphibolite. North-east of innermost Nordvestfjord (see Fig. 2); profile height about $1000 \mathrm{~m}$.

west and is only exposed on the Alfabet Nunatakker, while the eastern thrust dips to the east and can be traced for more than $25 \mathrm{~km}$ in western Hinks Land (Higgins 1982).

North-east of Charcot Land, on the north-east side of innermost Nordvestfjord, a very large-scale, recumbent, west-vergent isoclinal anticline makes up the eastern boundary of the window (Fig. 3). This fold nappe is sitting in the hanging wall and is made up by the cover rocks from outside of the window. The nappe, first recognised by Eduard Wenk and Helge Backlund in 1934 (Backlund in Koch 1955; Wenk 1956), is outlined by a conspicuous white marble unit that has an isoclinal fold closure some $25 \mathrm{~km}$ north-west of its first appearance opposite the front of Daugaard-Jensen Gletscher. However, the narrow closure that Wenk and Backlund observed from fjord level accounts for less than half of the magnitude of this fold nappe. Over its entire length, the structure could easily accommodate a translative movement of the proportions necessary to form the Charcot Land window, a minimum of 40 $\mathrm{km}$ displacement (Friderichsen \& Thrane 1998).

\section{Structures}

The broad structure of the Charcot Land window is an elongate N-S-trending dome (Fig. 2). Within the window, foliation trends have a general NW-SE strike and dip at shallow angles to the east. Lineations plunge at moderate angles eastwards, between north-east and south-east. Major folds have trends between $\mathrm{E}-\mathrm{W}$ and NW-SE, while minor folds have more variable trends and plunge directions.

The crystalline basement terrain east and north-east of Charcot Land, that forms part of the structurally overlying thrust sheet, exhibits a different pattern of structures. Friderichsen \& Thrane (1998) mapped a broad area of the allochthonous gneisses north-east of Charcot Land. They record the general foliation trends in eastern parts of their area as NE-SW to N-S with an eastwards dip, with linear elements plunging at moderate to shallow angles to the east or southeast; these were interpreted as Caledonian structures. The presence of major, recumbent, NW-verging folds suggests the NE-SW trends might be a response to Caledonian compression, while the N-S trends may relate to Caledonian extension, mainly seen as ductile top-down-to-the-east faults. In the western part of their area, Friderichsen \& Thrane (1998) noted the structural pattern as more diffuse, perhaps due to a 
less intense Caledonian overprinting of older and more complex pre-Caledonian structures. In general the foliation trends are NE-SW, with NW-plunging lineations.

Although the general foliation trends within the Charcot Land window are also broadly NW-SE, like those in the eastern areas of the overlying thrust sheets, the structures in Charcot Land are not interpreted as Caledonian. Lineations in Charcot Land also have much steeper eastward dips than in the thrust sheets. Further evidence that the Caledonian overprint within the window was generally weak is that the large Palaeoproterozoic granite intrusions cutting the basement gneisses in Charcot Land show no evidence of deformation. The only certain Caledonian structures are the planar cleavage in the diamictites of the Vendian Tillit Nunatak formation.

The major thrust along the east side of the Charcot Land window is well-defined in north-west Hinks Land (Fig. 2), but its northward continuation on the northeast side of Nordvestfjord was previously uncertain (Henriksen \& Higgins 1976). On the basis of their 1997 studies, Friderichsen \& Thrane (1998) proposed that the movement might have been taken up by the major nappe-like fold on the north-east side of the Charcot Land window (Fig. 3). The trend and westward sense of overturning of this nappe-like fold support the viewpoint that it is a Caledonian structure, although no other comparable structures were observed within the window. A thick low-grade succession of dark phyllitic shales observed in the crest of the fold has also been traced in the western nunataks of Charcot Land, substantially increasing the possible extent of the structure. In addition a thrust associated with this nappe-like major fold suggests that the total displacement was probably significantly more than the $40 \mathrm{~km}$ proposed by Henriksen \& Higgins (1976) and Henriksen (1986).

\section{Previous geochronological studies}

Hansen et al. (1981) analysed hornblende from amphibolite bands within the Charcot Land basement gneisses, and obtained K-Ar ages of $2097 \pm 105 \mathrm{Ma}$ and $2855 \pm 145 \mathrm{Ma}$. These were regarded as minimum ages for the amphibolite units of the crystalline complex. Rb-Sr whole rock analyses on samples of the gneisses were undertaken by Hansen (1976), but while the results did not yield any exact ages, there were indications that the gneisses might be more than 2200 Ma old. Based on lithology and age an Archaean ori- gin comparable to that of the Flyverfjord basement gneisses was thought likely. Rb-Sr whole rock analyses were also undertaken on samples of the widespread pegmatitic muscovite granite body, that intrudes both the basement gneisses and the supracrustal rocks in Charcot Land (Hansen et al. 1981); an age of $c$. $1850 \mathrm{Ma}$ was considered to indicate the approximate time of intrusion. K-Ar analyses on large muscovite crystals from the same granite yielded ages of $1760 \pm$ 60 and $1870 \pm 60 \mathrm{Ma}$, interpreted as a minimum age of emplacement (Hansen et al. 1981). Based on field observations, Steck (1971) argued that the granite was intruded after the main metamorphism of the supracrustal rocks, which was suggested to have taken place about 1900-1850 Ma ago (Hansen et al. 1981).

A young Rb-Sr biotite age of $402 \pm 10 \mathrm{Ma}$ from an amphibolite, together with a biotite-feldspar-wholerock isochron age of $402 \pm 8 \mathrm{Ma}$ for samples of the pegmatitic granite, were considered to reflect a Caledonian greenschist facies metamorphic overprint (Hansen et al. 1981).

Isotopic data from orthogneiss units in some of the other foreland areas exposed along the margin of the Caledonian orogen in East Greenland have yielded Palaeoproterozoic protolith ages, e.g. Kalsbeek et al. (1993) and Tucker et al. (1993) obtained Palaeoproterozoic ages for basement gneisses from the western part of Dronning Louise Land $\left(77^{\circ} \mathrm{N}, 25^{\circ} \mathrm{W}\right)$ and quartz porphyry bodies and grey granites within the Eleonore S $\varnothing$ window have yielded similar ages (Higgins \& Leslie 2004 , this volume). None of the so far dated foreland rock units have yielded convincing Archaean ages.

\section{Geochronology}

\section{Samples}

Two representative samples from the basement gneiss complex were studied. Sample 426040 is a fine-grained, light grey, granodioritic orthogneiss, and sample 426041 a dark grey, coarse-grained, granodioritic orthogneiss (Fig. 4). Both rock units exhibit a penetrative gneissosity and mineral lineation, and are cut by deformed light-coloured granite veins and undeformed pegmatitic muscovite granite veins. In the field, the age relationships between the two orthogneisses are very clear; the fine-grained orthogneiss (426040) intrudes and cuts the coarse-grained orthogneiss (426041). The limited field work undertaken in Charcot Land in 1997, and that undertaken earlier during the 1968- 


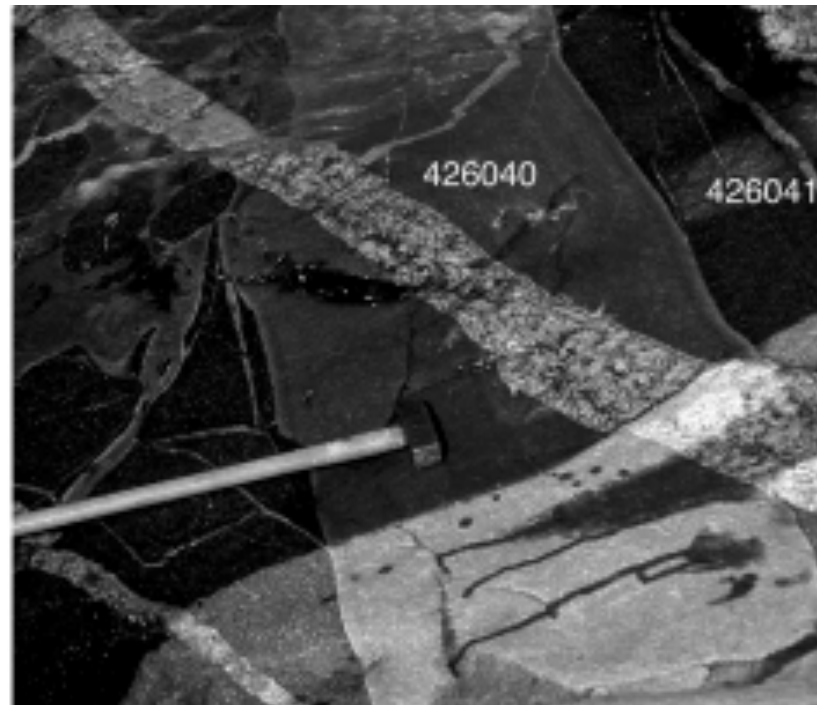

Fig. 4. Dark grey orthogneiss (426041) cut by a broad dyke of light grey orthogneiss (426040). Both are cut by later pegmatitic granite veins. Water flowing from right to left produces the colour differences between wet and dry rocks.

1972 Scoresby Sund expeditions (Henriksen 1986), indicate both gneiss types to be part of the regional basement gneiss complex, the oldest rocks exposed in Charcot Land.

\section{Analytical methods for the ion microprobe study}

$\mathrm{U}-\mathrm{Pb}$ dating of zircons was undertaken using the Cameca IMS 1270 ion probe at the NORDSIM laboratory, Swedish Museum of Natural History, Stockholm. Approximately 50 zircon grains from each sample were hand-picked, and mounted in a transparent epoxy resin together with reference zircons 91500 (from Ontario, Canada, with a weighted average ${ }^{207} \mathrm{~Pb} /{ }^{206} \mathrm{~Pb}$ age of $1065 \mathrm{Ma}$; Wiedenbeck et al. 1995). The zircon grains were polished sufficiently to expose any potentially older cores. The mounts were examined by reflected light microscopy and by backscatter imaging in a scanning electron microscope and then coated with c. $30 \mathrm{~nm}$ of gold. Analytical procedures are similar to those described by Schuhmacher et al. (1994) and Whitehouse et al. (1997). Calibration of $\mathrm{Pb} / \mathrm{U}$ ratios follows procedures similar to those used by the ion probe group at the Australian National University (Williams 1998), and is based on observed relationships between $\mathrm{Pb} / \mathrm{U}$ and $\mathrm{UO}_{2} / \mathrm{U}$, during the same analytical run. Results are given as discordia line intercept ages.
The ages were calculated using Isoplot/Ex (Ludwig 1999).

\section{Analytical results}

The U-Pb zircon data (Table 1) are presented in conventional concordia diagrams (Fig. 6; $1 \sigma$ error ellipses).

\section{Sample 426041}

Most of the zircons in sample 426041 are elongate, prismatic and clear, with sizes ranging from 100 to $400 \mathrm{~mm}$, most commonly between 200 and $250 \mathrm{~mm}$. They contain solid homogenous cores, some of which show oscillatory zonation. The rims are broad, metamict and show zonation. From the backscatter images, it is not clear whether the rims are metamorphic or simply alteration rims (Fig. 5). However, there is a clear chemical variation, with the rims having much lower $\mathrm{Th} / \mathrm{U}$ ratios $(0.02-0.07)$ than the cores (0.190.36), and also containing more common lead (Table 1). The variation in the $\mathrm{Th} / \mathrm{U}$ ratios indicates that the rims may have a metamorphic origin, while the higher common lead content may be a result of alteration of the rims. In the concordia diagram (Fig. 6A), all the analyses (rims as well as cores) fall on the same discordia line. The upper intercept age is $1916 \pm 21$ $\mathrm{Ma}$ and the lower intercept date of $443 \pm 25 \mathrm{Ma}$ (MSWD $=10.9$ ), where the upper intercept is interpreted as the best approximation of the crystallisation age of the gneiss protolith. Most of the rims plot on the discordia line, indicating that they must have a Palaeoproterozoic origin very close in age to the protolith, e.g. the rock must have been exposed to metamor-

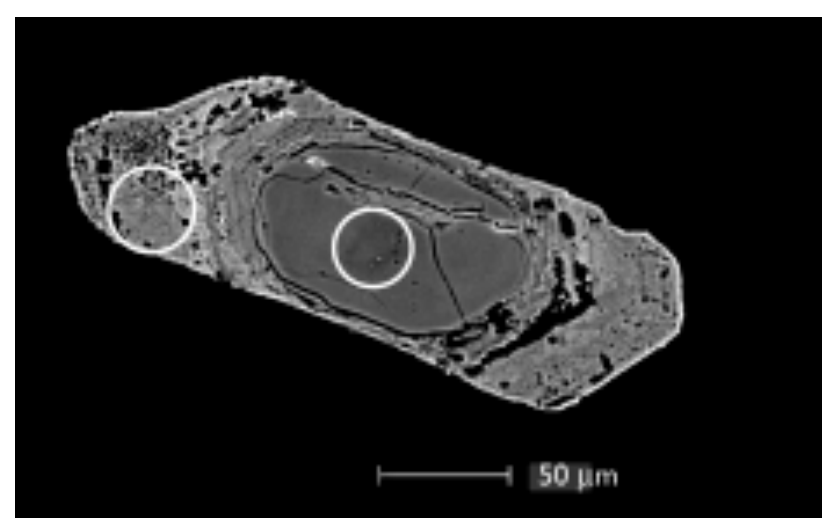

Fig. 5. Backscatter image of zircon number 7 from sample 426041 The circles indicate the ion probe analysis sites. 
Table 1. SIMS U-Th-Pb analytical data and derived ages

\begin{tabular}{|c|c|c|c|c|c|c|c|c|c|c|c|c|c|c|c|c|c|c|}
\hline \multirow{2}{*}{$\begin{array}{c}\text { Sample/ } \\
\text { spot\# }\end{array}$} & \multirow{2}{*}{$\begin{array}{c}U \\
\mathrm{PPm}\end{array}$} & \multirow{2}{*}{$\begin{array}{c}\mathrm{Pb} \\
\mathrm{Ppm}\end{array}$} & \multirow{2}{*}{$\begin{array}{c}\text { Th } \\
\text { Ppm }\end{array}$} & \multirow{2}{*}{$\begin{array}{l}\text { Th/U } \\
\text { meas. }\end{array}$} & \multirow{2}{*}{$\begin{array}{c}f \% \\
\text { common }\end{array}$} & \multirow{2}{*}{$\frac{{ }^{207} \mathrm{~Pb}}{{ }^{206} \mathrm{~Pb}}$} & \multirow{2}{*}{$\begin{array}{c} \pm \sigma \\
\%\end{array}$} & \multirow{2}{*}{$\frac{{ }^{207} \mathrm{~Pb}}{{ }^{235} \mathrm{U}}$} & \multirow{2}{*}{$\begin{array}{c} \pm \sigma \\
\%\end{array}$} & \multirow{2}{*}{$\frac{{ }^{206} \mathrm{~Pb}}{{ }^{238} \mathrm{U}}$} & \multirow{2}{*}{$\begin{array}{c} \pm \sigma \\
\%\end{array}$} & \multirow{2}{*}{$\begin{array}{c}\text { Disc. } \\
\%\end{array}$} & \multicolumn{4}{|c|}{ Ages (Ma) } & \multirow[b]{2}{*}{$\frac{{ }^{206} \mathrm{~Pb}}{{ }^{238} \mathrm{U}}$} & \multirow[b]{2}{*}{$\pm \sigma$} \\
\hline & & & & & & & & & & & & & $\frac{{ }^{207} \mathrm{~Pb}}{{ }^{206} \mathrm{~Pb}}$ & $\pm \sigma$ & $\frac{{ }^{207} \mathrm{~Pb}}{{ }^{235} \mathrm{U}}$ & $\pm \sigma$ & & \\
\hline \multicolumn{19}{|l|}{426040} \\
\hline $9 c$ & 351 & 137 & 86 & 0.25 & 0.08 & 0.1170 & 0.29 & 5.275 & 0.82 & 0.327 & 0.77 & -5.3 & 1911 & 5 & 1865 & 7 & 1824 & 12 \\
\hline $6 c$ & 473 & 148 & 134 & 0.28 & 0.07 & 0.1125 & 0.33 & 4.041 & 0.82 & 0.261 & 0.75 & -21.1 & 1840 & 6 & 1642 & 7 & 1493 & 10 \\
\hline $5 c$ & 717 & 192 & 279 & 0.39 & 1.10 & 0.1034 & 0.46 & 2.713 & 0.92 & 0.190 & 0.79 & -36.3 & 1686 & 8 & 1332 & 7 & 1123 & 8 \\
\hline $1 c$ & 1583 & 245 & 727 & 0.46 & 1.29 & 0.0998 & 0.55 & 1.739 & 1.00 & 0.126 & 0.83 & -55.8 & 1620 & 10 & 1023 & 6 & 767 & 6 \\
\hline $3 c$ & 628 & 122 & 190 & 0.30 & 1.14 & 0.0996 & 0.92 & 2.243 & 1.26 & 0.163 & 0.87 & -42.7 & 1616 & 17 & 1195 & 9 & 975 & 8 \\
\hline $4 c$ & 856 & 158 & 362 & 0.42 & 0.18 & 0.0971 & 0.42 & 2.062 & 1.14 & 0.154 & 1.06 & -44.1 & 1569 & 8 & 1136 & 8 & 923 & 9 \\
\hline $2 c$ & 752 & 134 & 194 & 0.26 & 1.49 & 0.0958 & 0.59 & 2.007 & 1.12 & 0.152 & 0.96 & -43.8 & 1543 & 11 & 1118 & 8 & 912 & 8 \\
\hline $7 r$ & 7482 & 463 & 250 & 0.03 & 4.80 & 0.0527 & 5.96 & 0.425 & 6.01 & 0.058 & 0.77 & 15.9 & 317 & 130 & 359 & 18 & 366 & 3 \\
\hline \multicolumn{19}{|l|}{426041} \\
\hline $2 c$ & 302 & 110 & 83 & 0.27 & 0.09 & 0.1165 & 0.40 & 4.883 & 0.93 & 0304 & 0.83 & -11.6 & 1904 & 7 & 1799 & 8 & 1711 & 13 \\
\hline $13 c$ & 247 & 93 & 88 & 0.36 & 0.11 & 0.1143 & 0.49 & 4.857 & 1.19 & 0.308 & 1.09 & -8.3 & 1869 & 9 & 1795 & 10 & 1732 & 17 \\
\hline $14 c$ & 503 & 138 & 94 & 0.19 & 0.40 & 0.1115 & 0.42 & 3.635 & 0.93 & 0.236 & 0.83 & -27.7 & 1824 & 8 & 1557 & 7 & 1368 & 10 \\
\hline $4 c$ & 364 & 107 & 123 & 0.34 & 0.21 & 0.1107 & 0.41 & 3.707 & 0.97 & 0.243 & 0.87 & -25.1 & 1810 & 7 & 1573 & 8 & 1402 & 11 \\
\hline $2 r$ & 475 & 127 & 106 & 0.22 & 0.24 & 0.1086 & 0.39 & 3.424 & 0.95 & 0.229 & 0.87 & -27.9 & 1775 & 7 & 1510 & 8 & 1328 & 10 \\
\hline $1 c$ & 683 & 134 & 192 & 0.28 & 0.36 & 0.0999 & 0.41 & 2.288 & 0.93 & 0.166 & 0.84 & -41.9 & 1621 & 8 & 1208 & 7 & 991 & 8 \\
\hline $7 r$ & 3705 & 594 & 95 & 0.03 & 0.40 & 0.0935 & 0.29 & 1.827 & 0.88 & 0.142 & 0.83 & -45.8 & 1498 & 5 & 1055 & 6 & 854 & 7 \\
\hline $8 r$ & 3445 & 514 & 73 & 0.02 & 0.83 & 0.0924 & 0.33 & 1.727 & 0.90 & 0.136 & 0.83 & -47.3 & 1475 & 6 & 1019 & 6 & 820 & 6 \\
\hline $9 r$ & 2780 & 289 & 132 & 0.05 & 0.69 & 0.0750 & 0.58 & 0.992 & 1.09 & 0.096 & 0.92 & -46.7 & 1068 & 12 & 700 & 6 & 591 & 5 \\
\hline $15 r$ & 3761 & 349 & 159 & 0.04 & 1.59 & 0.0732 & 0.63 & 0.867 & 1.05 & 0.086 & 0.84 & -49.8 & 1019 & 13 & 634 & 5 & 531 & 4 \\
\hline $3 r$ & 3824 & 354 & 93 & 0.02 & 0.80 & 0.0693 & 0.52 & 0.823 & 0.98 & 0.086 & 0.83 & -43.2 & 909 & 11 & 609 & 5 & 532 & 4 \\
\hline $11 r$ & 3622 & 294 & 108 & 0.03 & 1.67 & 0.0598 & 0.80 & 0.630 & 1.16 & 0.076 & 0.85 & -21.2 & 597 & 17 & 496 & 5 & 475 & 4 \\
\hline $5 r$ & 3622 & 280 & 255 & 0.07 & 2.27 & 0.0548 & 0.87 & 0.542 & 1.22 & 0.072 & 0.86 & -11.4 & 403 & 19 & 440 & 4 & 447 & 4 \\
\hline
\end{tabular}

Errors on ratios and ages are quoted at $1 \sigma$ level.

$\mathrm{f} \%$ common is the fraction of common ${ }^{206} \mathrm{~Pb}$ estimated from the measured ${ }^{204} \mathrm{~Pb}$.

Disc. \% refers to the degree of discordance of the zircon analysis. 

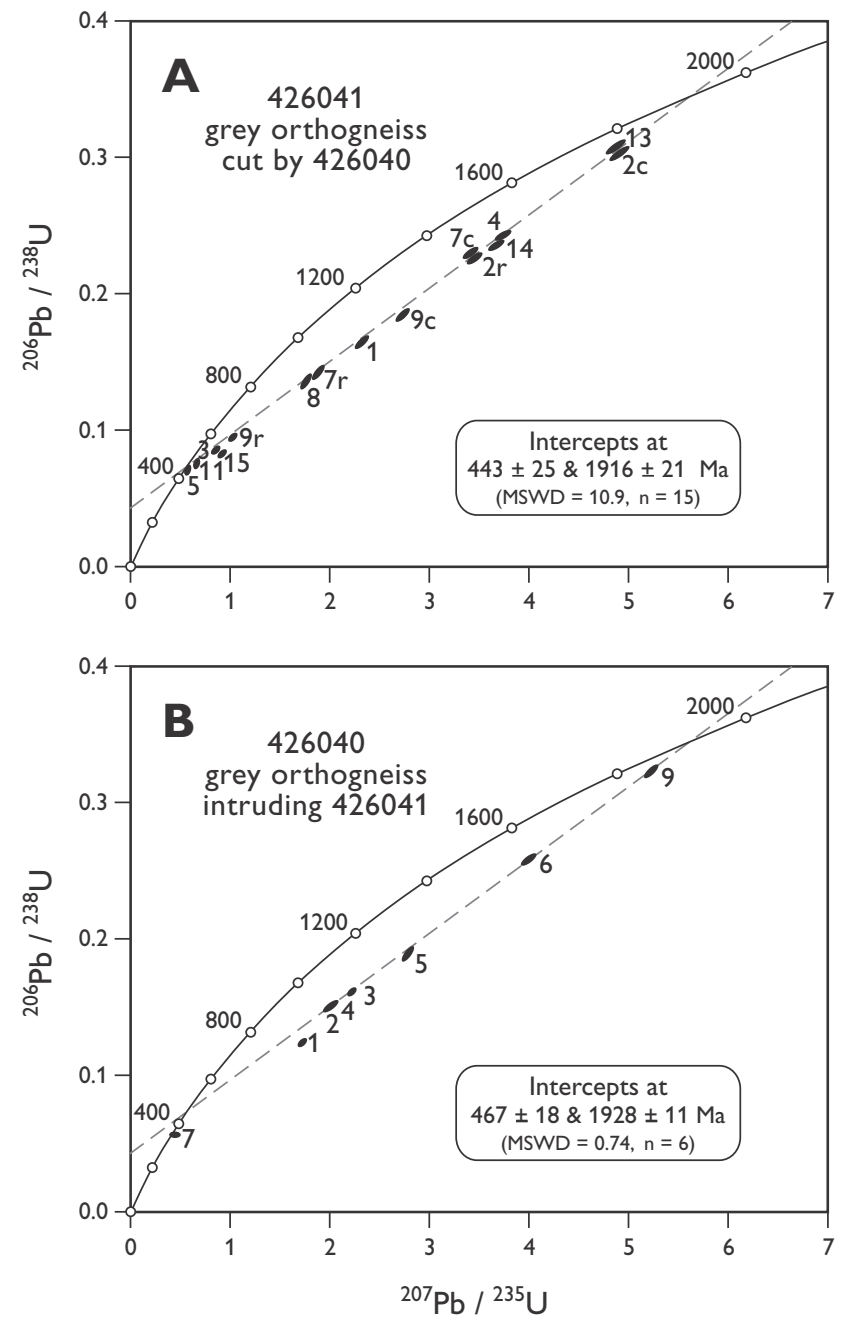

Fig. 6. U-Pb concordia diagrams for the two samples of orthogneiss from Charcot Land. A: Sample 426041. B: Sample 426040. Error ellipses show $1 \sigma$ errors and errors on the intercept ages are $2 \sigma$

phism soon after crystallisation of the protolith, and these rims have later suffered $\mathrm{Pb}$ loss. Only a few rims cluster around the lower intercept and could reflect the time when the gneiss suffered Caledonian metamorphism.

\section{Sample 426040}

The morphologies of the zircons in 426040 are very similar to those in sample 426041. Most have long prismatic shapes, but stubby grains also occur. The zircons are clear and range in size from 100 to $250 \mathrm{~mm}$. Both homogenous and oscillatory zoned cores are present, while the rims are often metamict. In this study mostly cores were analysed. They plot on a discordia line (Fig. 6B) yielding intercept ages of $1928 \pm 11 \mathrm{Ma}$ and $467 \pm 18 \mathrm{Ma}(\mathrm{MSWD}=0.74)$. Two rims were analysed; these do not plot on the discordia line, but one of them plots on the concordia line, yielding a ${ }^{206} \mathrm{~Pb} /$ ${ }^{238} \mathrm{U}$ age of $366 \pm 3 \mathrm{Ma}$.

\section{Discussion}

The two analysed samples of basement gneisses from the Charcot Land window yield identical upper intercept ages for the protolith within error, $1928 \pm 11$ and $1916 \pm 21 \mathrm{Ma}$. The fact that the two orthogneisses yield the same age demonstrates that several distinct magma pulses were emplaced during this time period. If the $\mathrm{Rb}-\mathrm{Sr}$ whole-rock age of c. 1850 Ma reported by Hansen et al. (1981) for the undeformed muscovite granite is valid, then the time of deformation and gneissification is bracketed between c. 1920 and $1850 \mathrm{Ma}$. The Palaeoproterozoic metamorphic effect seen in the growth of rims on zircons in sample 426041 might have been caused by the Palaeoproterozoic intrusive activity. The lower concordia intercepts suggesting Caledonian ages are indicative of some $\mathrm{Pb}$ loss and alteration of the zircons (Fig. 6), and can be linked to burial of the foreland beneath a several kilometre thick pile of Caledonian thrust sheets. Within the Charcot Land window limited Caledonian deformation is recorded, e.g. development of a planar cleavage in the diamictites of the Vendian Tillit Nunatak Formation, and associated folding in the underlying basement gneisses (Moncrieff 1989). However, Caledonian deformation was not pervasive and, as noted above, the Palaeoproterozoic muscovite granite body has no internal fabric.

The new age determinations reported here indicate that the protolith of the basement gneiss complex in Charcot Land is Palaeoproterozoic, rather than Archaean as suggested by Hansen (1976) and Hansen et al. (1981). At the current state of knowledge there is, in fact, no convincing isotopic evidence of the presence of Archaean basement rocks in any of the foreland windows along the western margin of the Caledonian orogen.

Volcano-sedimentary sequences of Palaeoproterozoic age are known in the Charcot Land and Eleonore Sø windows (Higgins et al. 2001), but are not known in the allochthonous thrust sheets that overlie the foreland windows. Similarly, the late Mesoproterozoic early Neoproterozoic Krummedal supracrustal sequence that is widely represented in the thrust sheets 
structurally above these windows is not present within them. It could, therefore, be argued that the known Archaean rock units, such as the allochthonous Flyverfjord infracrustal complex south of latitude $72^{\circ} 50^{\prime} \mathrm{N}$, represent a terrain that was accreted onto the Palaeoproterozoic foreland.

There remain many uncertainties in making regional assessments. For example, modern isotopic age data are still lacking for the crystalline basement rocks of the southern Gåseland window, while metasedimentary rocks found as infolded layers within the allochthonous crystalline basement gneisses north of latitude $72^{\circ} \mathrm{N}$ (Friderichsen \& Thrane 1998; Thrane \& Friderichsen 1999) are of uncertain age. The assumption that these infolded metasedimentary layers are related to the thick developments of the late Mesoproterozoic - early Neoproterozoic Krummedal sequence is not proven, and it cannot be excluded that they are equivalents of the Palaeoproterozoic Charcot Land supracrustal sequence. The absence of representatives of the Krummedal supracrustal sequence in the foreland windows could be considered as support for the view that this sequence was deposited far away from the Flyverfjord crystalline basement and that these units were juxtaposed during the Caledonian orogeny (Watt \& Thrane 2001).

The ages obtained from the basement gneiss complex in the Charcot Land foreland window are not dissimilar from the ages obtained on the allochthonous crystalline basement complexes north of $72^{\circ} 50^{\prime} \mathrm{N}$ (Rex \& Gledhill 1981; Kalsbeek et al. 1993; Thrane 2002), although the lithological make-up of the two basement complexes is different. Characteristic features of Charcot Land include the spectacular Palaeoproterozoic granitoid intrusions, which occur both as netveining dykes and as major undeformed plutons. Such characteristic features are uncommon in the allochthonous Palaeoproterozoic crystalline basement rocks to the north. It is the author's opinion that the grey orthogneisses in the allochthonous crystalline basement north of $72^{\circ} 50^{\prime} \mathrm{N}$ originally had much the same appearance as the Charcot Land orthogneisses, but that the former suffered much more intense deformation during the Caledonian orogeny. Thus, the Charcot Land basement gneisses and the allochthonous basement gneiss complexes north of $72^{\circ} 50^{\prime} \mathrm{N}$ could once have been parts of the same terrain prior to separation by Caledonian thrusting, with the major nappelike structure on the north-east side of the Charcot Land window taking up the thrust movement. Alternatively, the two Palaeoproterozoic basement terrains may originally have been unrelated, and with different histories, but have been brought into close proximity by thrusting during the Caledonian orogeny.

\section{Acknowledgements}

The isotope data described in this paper were acquired at the NORDSIM Laboratory at the Swedish Museum of Natural History, Stockholm. Critical comments on the manuscript by Johan D. Friderichsen, Adam A. Garde, A.K. Higgins and Feiko Kalsbeek are greatly appreciated. This project was based on funding from the Danish Natural Science Research Council. David Gee and Clark Friend are thanked for constructive reviews of the manuscript.

\section{References}

Escher, J.C. \& Jones, K.A. 1998: Caledonian thrusting and extension in Fræenkel Land, East Greenland $\left(73^{\circ}-73^{\circ} 30^{\prime} \mathrm{N}\right)$ : preliminary results. In: Higgins, A.K. \& Frederiksen, K.S. (eds): Caledonian geology of East Greenland $72^{\circ}-74^{\circ} \mathrm{N}$ : preliminary reports from the 1997 expedition. Danmarks og Grønlands Geologiske Undersøgelse Rapport 1998/28, 29-42.

Friderichsen, J.D. \& Thrane, K. 1998: Caledonian and pre-Caledonian geology of the crystalline complexes of the Stauning Alper, Nathorst Land and Charcot Land, East Greenland. In: Higgins, A.K. \& Frederiksen, K.S. (eds): Caledonian geology of East Greenland $72^{\circ}-74^{\circ} \mathrm{N}$ : preliminary reports from the 1997 expedition. Danmark og Grønlands Geologiske Undersøgelse Rapport 1998/28, 55-71.

Hansen, B.T. 1976: A geochronological study of polymetamorphism within the Caledonian mountain belt of central East Greenland, 77 pp. Dissertation 5761. Zurich: Swiss Federal Institute of Technology.

Hansen, B.T., Steiger, R.H. \& Higgins, A.K. 1981: Isotopic evidence for a Precambrian metamorphic event within the Charcot Land window, East Greenland Caledonian fold belt. Bulletin Geological Society of Denmark 29, 151-160.

Hartz, E.H. \& Andresen, A. 1995: Caledonian sole thrust of central East Greenland: a crustal scale Devonian extensional detachment. Geology 23, 637-640.

Henriksen, N. 1986: Geological map of Greenland, 1:500 000, Scoresby Sund, sheet 12. Descriptive text, 27 pp. Copenhagen: Geological Survey of Greenland.

Henriksen, N. \& Higgins, A.K. 1969: Preliminary results of mapping in the crystalline complex around Nordvestfjord, Scoresby Sund, East Greenland. Rapport Grønlands Geologiske Undersøgelse 21, 2-20.

Henriksen, N. \& Higgins, A.K. 1976: East Greenland Caledonian fold belt. In: Escher, A. \& Watt, W.S. (eds): Geology of Greenland, 182-246. Copenhagen: Geological Survey of Greenland. Higgins, A.K. 1982: Geological map of Greenland, 1:100 000, 
Charcot Land $71 \varnothing .4$ Nord. Krummedal $71 \varnothing .4$ Syd. Descriptive text, 26 pp., 2 maps. Copenhagen: Geological Survey of Greenland.

Higgins, A.K. \& Leslie, A.G. 2000: Restoring thrusting in the East Greenland Caledonides. Geology 28, 1019-1022.

Higgins, A.K. \& Leslie, A.G. 2004: The Eleonore Sø and Målebjerg foreland windows, East Greenland Caledonides, and the demise of the 'stockwerke' concept. In: Higgins, A.K. \& Kalsbeek, F. (eds): East Greenland Caledonides: stratigraphy, structure and geochronology. Geological Survey of Denmark and Greenland Bulletin 6, 77-93 (this volume).

Higgins, A.K., Leslie, A.G. \& Smith, M.P. 2001: Neoproterozoic Lower Palaeozoic stratigraphical relationships in the marginal thin-skinned thrust belt of the East Greenland Caledonides: comparisons with the foreland of Scotland. Geological Magazine 138, 143-160

Higgins, A.K. et al. 2004: The foreland-propagating thrust architecture of the East Greenland Caledonides $72^{\circ}-75^{\circ} \mathrm{N}$. Journal of the Geological Society (London) 161, 1009-1026.

Hull, J.M. \& Friderichsen, J.D. 1995: Geology of basement rocks in northern North-East and eastern North Greenland. In: Higgins, A.K. (ed.): Express report: eastern North Greenland and North-East Greenland 1995, 11-21. Unpublished report, Geological Survey of Greenland, Copenhagen.

Kalsbeek, F., Nutman, A.P. \& Taylor, P.N. 1993: Palaeoproterozoic basement province in the Caledonian fold belt of NorthEast Greenland. Precambrian Research 63, 163-178.

Kalsbeek, F., Thrane, K., Nutman, A.P. \& Jepsen, H.F. 2000: Late Mesoproterozoic to early Neoproterozoic history of the East Greenland Caledonides: evidence for Grenvillian orogenesis? Journal of the Geological Society (London) 157, 1215-1225.

Koch, L. 1955: Report on the expeditions to central East Greenland 1926-1939. Conducted by Lauge Koch. Part II. Meddelelser om Grønland 143(2), 642 pp.

Leslie, A.G. \& Higgins, A.K. 1998: On the Caledonian geology of Andreé Land, Eleonore S $\varnothing$ and adjacent nunataks $\left(73^{\circ} 30^{\prime}-\right.$ $74^{\circ} \mathrm{N}$ ), East Greenland. In: Higgins, A.K. \& Frederiksen, K.S. (eds): Caledonian geology of the East Greenland Caledonides $72^{\circ}-74^{\circ} \mathrm{N}$ : preliminary reports from the 1997 expedition. Danmarks og Grønlands Geologiske Undersøgelse Rapport 1998/28, 11-27.

Ludwig, K.R. 1999: Isoplot/Ex version 2.00 - A geochronological toolkit for Microsoft Excel. Berkeley Geochronology Center, Special Publication 2.

Moncrieff, A.C.M. 1989: The Tillite Group and related rocks of East Greenland: implications for Late Proterozoic palaeogeography. In: Gayer, R.A. (ed.): The Caledonide geology of Scandinavia, 285-297. London: Graham \& Trotman.

Phillips, W.E.A., Stillman, C.J., Friderichsen, J.D. \& Jemelin, L. 1973: Preliminary results of mapping in the western gneiss and schist zone around Vestfjord and inner Gåsefjord, southwest Scoresby Sund. Rapport Grønlands Geologiske Undersøgelse 58, 17-32.

Rex, D.C. \& Gledhill, A. 1974: Reconnaissance geochronology of the infracrustal rocks of Flyverfjord, Scoresby Sund, East Greenland. Bulletin Geological Society of Denmark 23, 49-54.

Rex, D.C. \& Gledhill, A. 1981: Isotopic studies in the East Green- land Caledonides $\left(72^{\circ}-74^{\circ} \mathrm{N}\right)$ - Precambrian and Caledonian ages. Rapport Grønlands Geologiske Undersøgelse 104, 4772 .

Schuhmacher, M., de Chambost, E., McKeegan, K.D., Harrison, T.M. \& Migeon, H. 1994: In situ dating of zircon with the CAMECA ims 1270. In: Benninghoven, A. (ed.): Secondary Ion Mass Spectrometry SIMS IX, 919-922. Chichester: John Wiley \& Sons.

Sønderholm, M. \& Tirsgaard, H. 1993: Lithostratigraphic framework of the Upper Proterozoic Eleonore Bay Supergroup of East and North-East Greenland. Bulletin Grønlands Geologiske Undersøgelse 167, 38 pp.

Steck, A. 1971: Kaledonische Metamorphose der Praekambrischen Charcot Land Serie, Scoresby Sund, Ost-Grönland. Bulletin Grønlands Geologiske Undersøgelse 97, 69 pp. (also Meddelelser om Grønland 192(3)).

Strachan, R.A., Holdsworth, R.E., Friderichsen, J.D. \& Jepsen, H.F. 1992: Regional Caledonian structure within an oblique convergence zone, Dronning Louise Land, NE Greenland. Journal of the Geological Society (London) 149, 359-371.

Thrane, K. 2002: Relationships between Archaean and Palaeoproterozoic basement complexes in the southern part of the East Greenland Caledonides: an ion microprobe study. Precambrian Research 113, 19-42.

Thrane, K. \& Friderichsen, J.D. 1999: The Häsi Bjerge orthogneiss complex, the Foldebjerg orthogneisses and a brief account of a visit to the Nordvestfjord nappe, East Greenland Caledonides. In: Higgins, A.K. \& Frederiksen, K.S. (eds): Geology of East Greenland $72^{\circ}-75^{\circ} \mathrm{N}$, mainly Caledonian: preliminary reports from the 1998 expedition. Danmarks og Grønlands Geologiske Undersøgelse Rapport 1999/19, 37-41.

Tucker, R.D., Dallmeyer, R.D. \& Strachan, R.A. 1993: Age and tectonothermal record of Laurentian basement, Caledonides of NE Greenland. Journal of the Geological Society (London) 150, 371-379.

Watt, G.R. \& Thrane, K. 2001: Early Neoproterozoic events in East Greenland. Precambrian Research 110, 165-184.

Wenk, E. 1956: Alpines und Ostgrönländisch-Kaledonisches Kristalline, ein Tektonish-Petrogenetischer Vergleich. Verhandlungen des Naturforscher Gesellschaftes in Basel 67, 75-102.

Wenk, E. 1961: On the crystalline basement and the basal part of the pre-Cambrian Eleonore Bay Group in the south-west part of Scoresby Sund. Meddelelser om Grønland 168(1), 54 pp.

Whitehouse, M.J., Claesson, S., Sunde, T. \& Vestin, J. 1997: Ion microprobe U-Pb zircon geochronology and correlation of Archaean gneisses from the Lewisian Complex of Gruinard, north-western Scotland. Geochimica et Cosmochimica Acta 61, 4429-4438

Wiedenbeck, M., Allé, P., Corfu, F., Griffin, W.L., Meier, M., Oberli, F., Von Quardt, A., Roddick, J.C. \& Spiegel, W. 1995: Three natural zircon standards for U-Th-Pb, Lu-Hf, trace element and REE analyses. Geostandards Newsletter 19, 1-23.

Williams, I.S. 1998: U-Th-Pb geochronology by ion microprobe. In: McKibben, M.A., Shanks III, W.C. \& Ridley, W.I. (eds): Applications of microanalytical techniques to understanding mineralizing processes. Reviews in Economic Geology 7, 1-35. 